

\section{NOTICE}

The submitted manuscript has been offered by an employee of the Alliance for Sustainable Energy, LLC (ASE), a contractor of the US Government under Contract No. DE-AC36-08-GO28308. Accordingly, the US Government and ASE retain a nonexclusive royalty-free license to publish or reproduce the published form of this contribution, or allow others to do so, for US Government purposes.

This report was prepared as an account of work sponsored by an agency of the United States government. Neither the United States government nor any agency thereof, nor any of their employees, makes any warranty, express or implied, or assumes any legal liability or responsibility for the accuracy, completeness, or usefulness of any information, apparatus, product, or process disclosed, or represents that its use would not infringe privately owned rights. Reference herein to any specific commercial product, process, or service by trade name, trademark, manufacturer, or otherwise does not necessarily constitute or imply its endorsement, recommendation, or favoring by the United States government or any agency thereof. The views and opinions of authors expressed herein do not necessarily state or reflect those of the United States government or any agency thereof.

Available electronically at http://www.osti.gov/bridge

Available for a processing fee to U.S. Department of Energy and its contractors, in paper, from:

U.S. Department of Energy

Office of Scientific and Technical Information

P.O. Box 62

Oak Ridge, TN 37831-0062

phone: 865.576.8401

fax: 865.576 .5728

email: mailto:reports@adonis.osti.gov

Available for sale to the public, in paper, from:

U.S. Department of Commerce

National Technical Information Service

5285 Port Royal Road

Springfield, VA 22161

phone: 800.553.6847

fax: 703.605.6900

email: orders@ntis.fedworld.gov

online ordering: http://www.ntis.gov/ordering.htm 


\title{
Proposal for a Vehicle Level Test Procedure to Measure Air Conditioning Fuel Use
}

\author{
John Rugh \\ National Renewable Energy Laboratory
}

\begin{abstract}
The air-conditioning $(\mathrm{A} / \mathrm{C})$ compressor load significantly impacts the fuel economy of conventional vehicles and the fuel use/range of plug-in hybrid electric vehicles (PHEV). A National Renewable Energy Laboratory (NREL) vehicle performance analysis shows the operation of the air conditioner reduces the charge depletion range of a 40 -mile range PHEV from $18 \%$ to $30 \%$ in a worst case hot environment. Designing for air conditioning electrical loads impacts PHEV and electric vehicle (EV) energy storage system size and cost. While automobile manufacturers have climate control procedures to assess $\mathrm{A} / \mathrm{C}$ performance, and the U.S. EPA has the $\mathrm{SCO} 3$ drive cycle to measure indirect $\mathrm{A} / \mathrm{C}$ emissions, there is no automotive industry consensus on a vehicle level $\mathrm{A} / \mathrm{C}$ fuel use test procedure. With increasing attention on $\mathrm{A} / \mathrm{C}$ fuel use due to increased regulatory activities and the development of PHEVs and EVs, a test procedure is needed to accurately assess the impact of climate control loads.

A vehicle thermal soak period is recommended, with solar lamps that meet the SCO3 requirements or an alternative heating method such as portable electric heaters. After soaking, the vehicle is operated over repeated drive cycles or at a constant speed until steady-state cabin air temperature is attained. With this method, the cooldown and steady-state $\mathrm{A} / \mathrm{C}$ fuel use are measured. This method can be run at either different ambient temperatures to provide data for the GREEN-MAC-LCCP model temperature bins or at a single representative ambient temperature. Vehicles with automatic climate systems are allowed to control as designed, while vehicles with manual climate systems are adjusted to approximate expected climate control settings. An A/C off test is also run for all drive profiles. This procedure measures approximate real-world $\mathrm{A} / \mathrm{C}$ fuel use and assesses the impact of thermal load reduction strategies.
\end{abstract}

\section{INTRODUCTION}

When a vehicle $\mathrm{A} / \mathrm{C}$ system is operated, the compressor can be a significant power drain in the engine, depending on the ambient conditions. An NREL analysis found that the U.S. consumes about 7 billion gallons of fuel a year for cooling and dehumidifying light duty vehicles [1]. In fuel efficient vehicles, the impact of the $\mathrm{A} / \mathrm{C}$ system is more apparent because the fuel used for $\mathrm{A} / \mathrm{C}$ is a larger percentage of the overall vehicle fuel use. In vehicles with electric powertrains such as PHEVs and EVs, total energy management is essential. A/C energy use will increase the size and cost of the energy storage system (ESS) in order to meet the target performance parameters. 
The use of air conditioning impacts the charge-depleting (CD) range of PHEVs. NREL ran a simulation of a PHEV with an electric range of 40 miles (PHEV40) using vehicle simulation software. The vehicle was a midsized parallel hybrid sedan with an $81.9 \mathrm{~kW}$ engine and a $51.8 \mathrm{~kW}, 18.5 \mathrm{kWh}$ Li-ion battery [2]. Assuming a conventional HFC-134a air conditioning system operated in a Phoenix, AZ summer environment, a cooldown $\mathrm{A} / \mathrm{C}$ load followed by a lower steady-state $\mathrm{A} / \mathrm{C}$ load was applied to the vehicle. The vehicle was run over repeated drive cycles until the charge-sustaining (CS) mode was attained. Figure 1 shows that the CD range was reduced $18 \%$ for the USO6 drive cycle and 30\% over the UDDS drive cycle. Similar results were attained for an EV.

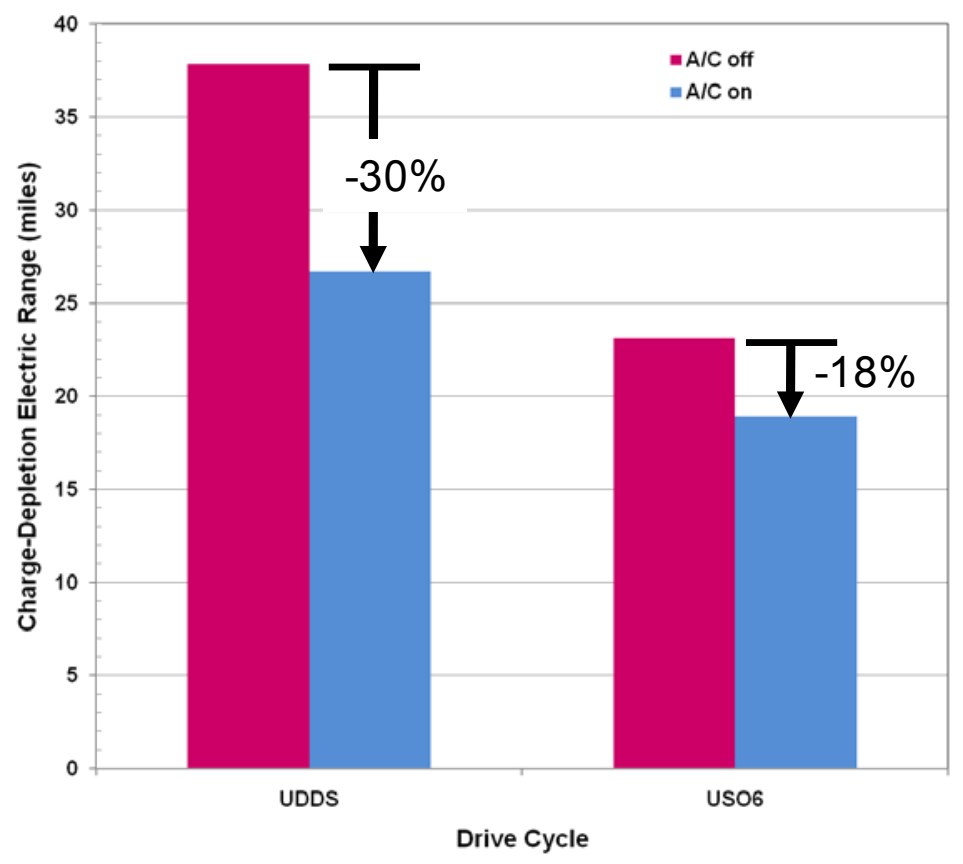

Figure 1. PHEV Charge-Depletion Electric Range over the UDDS and USO6 Drive Cycles

In recent years, $\mathrm{A} / \mathrm{C}$ fuel use has received increased attention from regulatory agencies. In the EU, one technique available to automobile manufacturers to reduce $\mathrm{CO}_{2}$ emissions from the mandatory $130 \mathrm{~g} \mathrm{CO} / \mathrm{km}$ to the target $120 \mathrm{~g} \mathrm{CO}_{2} / \mathrm{km}$ is to improve $\mathrm{A} / \mathrm{C}$ system efficiency [3]. The California Air Resources Board (CARB) has considered GHG emissions from automotive $\mathrm{A} / \mathrm{C}$ by including a credit for variable displacement compressors (VDC) in the Pavley 1493 bill [4,5] and included credits for reducing indirect $\mathrm{A} / \mathrm{C}$ emissions in an environmental performance labeling regulation [6]. In June 2009, CARB passed a regulation to reduce the thermal loads in vehicles to reduce GHG emissions due to A/C [7]. For model year 2008 vehicles, the U.S. EPA modified the way the fuel economy was calculated for window stickers and included A/C usage [8]. Recently the U.S. EPA and DOT issued a joint rulemaking proposal to harmonize fuel economy and GHG emissions regulations [9]. As part of the regulation, the EPA is considering credits for $\mathrm{A} / \mathrm{C}$ system improvements that reduce GHG emissions. This increase in regulatory attention has increased the need for a test procedure to quantify the impact of $\mathrm{A} / \mathrm{C}$ use on fuel consumption.

Due to the EU ban on HFC-134a in 2011, the automotive industry has been working to develop an alternative refrigerant. Composed automotive manufacturers, suppliers, and chemical company engineers, a global team developed the GREEN-MAC-LCCP spreadsheet to assess the environmental performance of refrigerants [10]. The spreadsheet is available on the U.S EPA website [11] and was converted into SAE standard J2766 [12]. The

Page 2 of 9 
spreadsheet currently uses bench-top $\mathrm{A} / \mathrm{C}$ data to characterize $\mathrm{A} / \mathrm{C}$ performance. The energy consumed by the $\mathrm{A} / \mathrm{C}$ system is converted to fuel use assuming an incremental engine efficiency. While bench data is useful to characterize the performance of the $\mathrm{A} / \mathrm{C}$ system, other vehicle systems and the $\mathrm{A} / \mathrm{C}$ control methodology impact $\mathrm{A} / \mathrm{C}$ fuel use.

In 2009, the global team considered modifying the spreadsheet to accept vehicle level A/C fuel use data. This provided an opportunity to review and assess industry $\mathrm{A} / \mathrm{C}$ fuel use measurement practices from a broad group of automobile manufacturers, suppliers, associations, and national labs. The review showed there is a wide variation in approaches to measure $\mathrm{A} / \mathrm{C}$ fuel use at the vehicle level with no industry consensus.

While the U.S. EPA currently measures the vehicle emissions over the SCO3 drive cycle, there is not an $\mathrm{A} / \mathrm{C}$ off test over the same cycle, so A/C fuel use cannot be directly calculated. As part of the recent joint rulemaking proposal, the U.S EPA has proposed performing an $\mathrm{A} / \mathrm{C}$ fuel use test at idle or modifying the environmental conditions of the $\mathrm{SCO} 3$ drive cycle [9].

\section{TEST OBJECTIVE}

There are three primary types of tests to measure $\mathrm{A} / \mathrm{C}$ fuel use at the vehicle level: equivalent capacity, equivalent temperature, and real world.

\section{EQUIVALENT CAPACITY}

For an equivalent capacity test, the goal is to measure the fuel required to provide the same thermal performance at the $\mathrm{A} / \mathrm{C}$ system level. Examples include tests to determine the impact of a new refrigerant or the impact of an improved efficiency technology such as an internal heat exchanger or evaporator. Although refrigerants can be compared at the bench level, testing on a vehicle accounts for varying engine speed, uneven air flow through the condenser, and under-hood conditions.

The goal of this test is to transfer the same amount of heat from the air flowing across the evaporator to the refrigerant in the same vehicle. This is essentially drawing a control volume around the $\mathrm{A} / \mathrm{C}$ system and having all inlet and outlet flows be equivalent. Parameters that need to be the same include: air flow across the

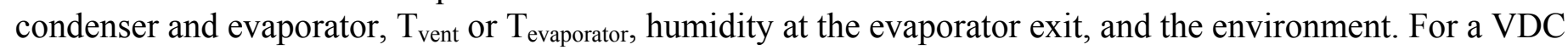
with automatic temperature control (ATC), it will be necessary to override the regular control and adjust the displacement to obtain the desired $\mathrm{T}_{\text {evaporator }}$. For systems with a fixed displacement compressor, the compressor RPM will need to be adjusted to obtain the desired $T_{\text {evaporator. }}$ Control of the cabin temperature at a constant level with a fixed recirculation air position in the same vehicle will also result in equivalent capacity. Since the vehicle is the same for all tests and the heat load into the cabin will not impact $\mathrm{A} / \mathrm{C}$ control, a thermal soak prior to $\mathrm{A} / \mathrm{C}$ operation is not required and this is a steady-state test.

\section{EQUIVALENT TEMPERATURE}

If the goal is to provide the same thermal performance at the passenger compartment, then an equivalent temperature test is necessary. This approach requires the same air temperature at the driver (or another location in the passenger compartment) from test to test. Although it would be preferable to have equivalent human thermal comfort, that is not the case in this test since comfort is also a function of humidity, air velocity, and incident radiation heat transfer. The equivalent temperature test can be viewed as drawing a control volume around the passenger compartment and $\mathrm{A} / \mathrm{C}$ system with equivalent air enthalpy in and out. Within the same vehicle, this type of test could be used to determine the fuel use impact of solar reflective glazings, improved Page 3 of 9 
control strategies, increased recirculation air, reheat reduction, a variable displacement compressor, or any thermal load reduction technology. For different vehicles, this type of test could be used to compare the impact of vehicle size or glass area. On the same vehicle, the climate system needs to be set the same for each test. Control of the climate system on different vehicles is challenging and would need to be correlated in advance. For vehicles with ATC, the $\mathrm{T}_{\text {setpoint }}$ to get the desired temperature at the driver would need to be determined in advance. For vehicles with manual control, the blower setting, temperature lever position, and recirculation control would need to be predetermined to obtain the desired driver air temperature. Depending on the researcher's objective, this test could be run as a thermal soak followed by a cooldown to steady-state thermal conditions or just as a shorter steady-state $\mathrm{A} / \mathrm{C}$ on test

\section{REAL WORLD}

If the goal is measuring real-world $\mathrm{A} / \mathrm{C}$ fuel use, then the capacity, temperature, and control should not be defined and the $\mathrm{A} / \mathrm{C}$ system should be allowed run as designed. The vehicle and climate control design decisions are then allowed to impact $\mathrm{A} / \mathrm{C}$ fuel use. The benefit is that consumers and regulators would have an estimate of the real A/C fuel use. A soak and cooldown would be required for this approach. Table 1 provides a summary of the three types of tests.

Table 1. Comparison of the A/C Fuel Use Test Approaches

\begin{tabular}{|l|l|l|l|l|}
\hline Type of Test & $\begin{array}{l}\text { Climate Control } \\
\text { Performance }\end{array}$ & Objective & Example & Application \\
\hline $\begin{array}{l}\text { Equivalent } \\
\text { Capacity }\end{array}$ & $\begin{array}{l}\text { Equal at the } \\
\text { HVAC level }\end{array}$ & $\begin{array}{l}\text { Impact of different } \\
\text { refrigerant or A/C } \\
\text { component }\end{array}$ & $\begin{array}{l}\text { HFO-1234yf } \\
\text { vs. R744 }\end{array}$ & Research \\
\hline $\begin{array}{l}\text { Equivalent } \\
\text { Temperature }\end{array}$ & $\begin{array}{l}\text { Equal at the } \\
\text { vehicle level }\end{array}$ & $\begin{array}{l}\text { Impact of thermal load } \\
\text { reduction, A/C control, } \\
\text { or interior change in the } \\
\text { same vehicle; compare } \\
\text { vehicle to vehicle }\end{array}$ & $\begin{array}{l}\text { Solar reflective } \\
\text { glazing; Ford } \\
\text { Escape vs. } \\
\text { Honda CRV }\end{array}$ & Research \\
\hline Real World & $\begin{array}{l}\text { Not equivalent, } \\
\text { but A/C system } \\
\text { operates as } \\
\text { designed }\end{array}$ & $\begin{array}{l}\text { Measure real-world fuel } \\
\text { use }\end{array}$ & $\begin{array}{l}\text { A/C fuel use } \\
\text { over FTP and } \\
\text { HFET }\end{array}$ & Real world \\
\hline
\end{tabular}

\section{PROCEDURE COMMON CHARACTERISTICS}

The three procedures have some common elements. They require a dynamometer in an environmental chamber where the temperature and humidity are controlled. There should be airflow over the front of the vehicle to achieve realistic condenser and radiator airflow rates. An $\mathrm{A} / \mathrm{C}$ off test and an $\mathrm{A} / \mathrm{C}$ on test are required with the same powertrain preconditioning and battery charging. Although a wind tunnel with uniform airflow over the entire vehicle is ideal, a large fan in front of the vehicle that is consistent with dynamometer vehicle speed would also be acceptable. 


\section{SOLAR LAMPS}

Solar lamps are required if climate control performance and design are to be assessed from a systems perspective. In order to measure the $\mathrm{A} / \mathrm{C}$ fuel use associated with a cooldown, the passenger compartment needs to be heated above ambient temperature, which occurs when a car is parked in the sun. A challenge is that a solar lamp system that meets the SCO3 requirements is expensive. While IR lamps can provide passenger compartment heat load at a lower cost, the spectral distribution is not representative of the sun and can lead to inaccurate results, particularly if testing solar reflective glazings. A barrier to outdoor testing is that repeatability is unlikely due to different environment conditions on different test days. Portable electric heaters can be used to simulate the heat load from the sun and eliminate the need for lamps. A pretest thermal analysis is required for each vehicle type to determine the proper heater settings. To assess the impact of thermal load reduction technologies such as solar reflective glazings, the heater power can be reduced by an amount determined in a pretest analysis. A disadvantage of electric heaters is that the air is heated, so the interior surfaces are not warmer than the interior air as in an outdoor solar soak case.

\section{RECOMMENDED A/C FUEL USE TEST PROCEDURE}

The purpose of the recommended test procedure is to measure the fuel use impact of all vehicle systems and components that impact occupant comfort. This is a research-oriented procedure that is intended to measure approximate real-world $\mathrm{A} / \mathrm{C}$ fuel use. An additional objective is to provide a process to gather data to populate the GREEN-MAC-LCCP spreadsheet with vehicle level A/C fuel use information. To measure the cooldown as well as steady-state $\mathrm{A} / \mathrm{C}$ fuel use, a thermal soak with solar lamps with the engine off is followed by vehicle operation with the $\mathrm{A} / \mathrm{C}$ on.

To measure the impact of thermal load reduction technologies, and also to enable measurement of the higher fuel use during cooldown, a thermal soak period is required in an environmental chamber. The thermal soak is followed by an $\mathrm{A} / \mathrm{C}$ cooldown that is run to passenger compartment thermal steady state. Solar lamps that meet the SCO3 requirement are recommended, as well as a soak long enough to obtain outdoor-like steady-state temperatures $(\sim 1.5-2 \mathrm{hr})$. The soak is performed with the windows and doors closed so realistic interior temperatures are attained. Thermal load reduction technologies and the resulting reduced interior temperatures can be assessed with this procedure. Since the vehicle cannot be occupied and driven during the soak, the engine will be off prior to driving; therefore, this procedure would be a cold start from an emissions perspective. As long as the vehicle control functions the same with $\mathrm{A} / \mathrm{C}$ off and $\mathrm{A} / \mathrm{C}$ on, the impact of the cold start should not impact the $\mathrm{A} / \mathrm{C}$ fuel use. The question of whether a solar soak is required for the $\mathrm{A} / \mathrm{C}$ off test will have to be determined. If data show the solar load does not impact vehicle systems other than $\mathrm{A} / \mathrm{C}$, then a solar load during $\mathrm{A} / \mathrm{C}$ off test would not be required.

The vehicle will be operated in an environmental chamber with a dynamometer and airflow over the front end. The solar lamps that meet SCO3 requirements will be on during the test to provide a realistic thermal load. If the vehicle is equipped with a solar sensor, the input into the $\mathrm{A} / \mathrm{C}$ control algorithm will be realistic. The chamber temperature and humidity should be controlled during test. A drive cycle is repeated, or the vehicle is run at a constant speed, until steady-state interior air temperature is attained. This could be defined as when a certain temperature is attained or when the rate of change of temperature drops to a certain level. Figure 2 shows what the temperature vs. time profile of this test procedure might look like. The cooldown A/C fuel use is the average of the $\mathrm{A} / \mathrm{C}$ fuel use of cycles 1 and 2, and the steady-state $\mathrm{A} / \mathrm{C}$ fuel use would be calculated from cycle 4 data.

Page 5 of 9 


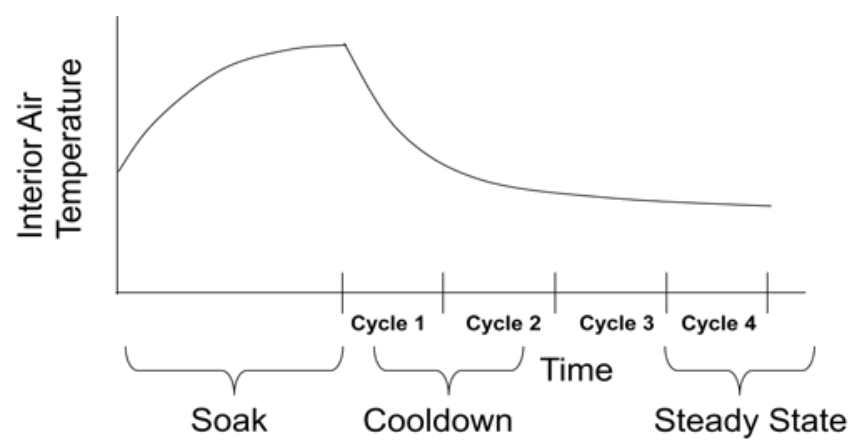

Figure 2. Hypothetical Temperature vs. Time Profile of a Soak and Cooldown A/C Fuel Use Test

This approach offers flexibility with regard to ambient conditions and drive cycle. $\mathrm{A} / \mathrm{C}$ off and $\mathrm{A} / \mathrm{C}$ on tests are run for all environmental conditions and at as many speeds or drive cycles as required. For example, to obtain A/C fuel use data for the temperature bin data defined in the GREEN-MAC-LCCP model, a single drive cycle could be run at the four temperatures identified in Table 2. If constant speed data are preferred, Table 2 would be completed for a constant speed. A simplified approach is to run the $\mathrm{A} / \mathrm{C}$ off and $\mathrm{A} / \mathrm{C}$ on tests for a single environment and a specific drive cycle. For example, one could use:

- $25^{\circ} \mathrm{C}$, average air temperature in U.S. when $\mathrm{A} / \mathrm{C}$ is operated [1]

- $66 \%$, average relative humidity in U.S. when $\mathrm{A} / \mathrm{C}$ is operated

- $850 \mathrm{~W} / \mathrm{m}^{2}, \mathrm{SCO} 3$ solar load

- $\mathrm{SCO} 3$ drive cycle.

Table 2. Example Test Conditions and Data Sheet

\begin{tabular}{|l|l|l|l|l|}
\hline Temperature & RH & Solar Load & A/C Fuel Use - Cooldown & A/C Fuel Use - Steady-state \\
\hline${ }^{\circ} \mathrm{C}$ & $\%$ & $\mathrm{~W} / \mathrm{m}^{2}$ & $\mathrm{~L} / 100 \mathrm{~km}$ or $\mathrm{L} / \mathrm{hr}$ & $\mathrm{L} / 100 \mathrm{~km}$ or L/hr \\
\hline 45 & TBD & TBD & & \\
\hline 35 & TBD & TBD & & \\
\hline 25 & TBD & TBD & & \\
\hline 15 & TBD & TBD & & \\
\hline
\end{tabular}

It is recommended to set the vents to the panel setting. For vehicles with ATC, adjust the temperature setpoint to $\sim 22^{\circ} \mathrm{C}$ and allow the blower and recirculation settings to be controlled automatically. This will allow the climate system to be control as designed. For vehicles with manual climate control, set the temperature lever to full cold and adjust the blower and recirculation settings according to a predetermined schedule that would be expected from operation in the field. This might consist of a high blower and outside air at the beginning of the cooldown, then transition to lower blower levels and higher recirculation air as the cabin cools down.

\section{DISCUSSION}

One issue is that the intent of the test could be "skirted" by the ATC setpoint temperature display being artificially low when the passenger compartment temperature is actually warm. In this case, the $\mathrm{A} / \mathrm{C}$ compressor power would be lower to maintain the passenger compartment at the warm temperature. The problem is that the real-world driver would set the temperature setpoint lower to get comfortable, cause the $\mathrm{A} / \mathrm{C}$ compressor power Page 6 of 9 
to increase, and use more fuel. While differences between manufacturer's ATC display temperatures are to be expected, a potential solution may be to establish an allowable interior temperature range.

A disadvantage of this procedure is that it will be costly and time consuming. Environmental chamber time and dynamometer time is expensive. If the soak is performed in the same chamber as the dynamometer, then the cost is amplified because the dynamometer cannot be used for a different test. Running these tests out to thermal steady state will also use more chamber time. Another disadvantage is that the impact of improved thermal comfort technology such as climate control seating is not assessed.

Another challenge with measuring $\mathrm{A} / \mathrm{C}$ fuel use is that it is a fraction of the overall vehicle fuel use. With the $\mathrm{A} / \mathrm{C}$ fuel use calculated as the difference between $\mathrm{A} / \mathrm{C}$ on and $\mathrm{A} / \mathrm{C}$ off data, small variations in overall vehicle fuel use could lead to large uncertainty in A/C fuel use data. Multiple tests could be required to determine A/C fuel use with reasonable confidence.

Vehicle fuel consumption is commonly reported in $\mathrm{L} / 100 \mathrm{~km}$. On drive cycles with longer idle periods such as the UDDS, the A/C fuel use is higher to cover the same miles as a higher average speed drive cycle. While cycle speed dependent $\mathrm{A} / \mathrm{C}$ fuel use data can provide useful information, reporting the $\mathrm{A} / \mathrm{C}$ fuel use as a rate in $\mathrm{L} / \mathrm{hr}$ eliminates the speed dependency and is a more consistent way to compare $\mathrm{A} / \mathrm{C}$ fuel use. Differences in condenser air flow and acceleration/deceleration losses for belt driven compressors will still be embedded in the $\mathrm{A} / \mathrm{C}$ fuel use rate.

One issue is how to compare $\mathrm{A} / \mathrm{C}$ systems with different cooldown rates. An automobile manufacturer might choose to incorporate a large $\mathrm{A} / \mathrm{C}$ system to cool occupants quickly, while another may choose a low power system that cools slowly. The fuel use during the cooldown for the large system would be high but the duration would be short. Just comparing cooldown $\mathrm{A} / \mathrm{C}$ fuel use would not be appropriate. One solution is to calculate an average $\mathrm{A} / \mathrm{C}$ fuel use by weighting the cooldown and steady-state components. The larger system would have a lower weighting for the cooldown since it occurs less frequently than the slower system. The weighting factors could be determined by vehicle and $\mathrm{A} / \mathrm{C}$ use characteristics.

Another item to consider is the use of this procedure for PHEVs and EVs. Both of these vehicles will have electric $\mathrm{A} / \mathrm{C}$ compressors and the procedure should be applicable. For a PHEV, it is recommended to run in charge-sustaining mode over the drive cycles so the thermal cooldown and steady-state data are not confounded by a battery discharge and steady state operation. For an EV, the A/C impact can be reported in $\mathrm{kWh} / 100 \mathrm{~km}$ or average $\mathrm{kW}$. Thermally preconditioning the passenger compartment using grid power to operate the on-board $\mathrm{A} / \mathrm{C}$ system is a method to increase electric range. The impact of this strategy could be measured with the proposed test procedure by operating the $\mathrm{A} / \mathrm{C}$ system during the soak.

\section{SUMMARY/CONCLUSIONS}

Climate control significantly degrades PHEV and EV performance (fuel consumption and range) and detrimentally impacts energy storage system size and cost. $\mathrm{A} / \mathrm{C}$ fuel use has been subject to increased regulatory activities. There is no automotive industry consensus on a vehicle-level $\mathrm{A} / \mathrm{C}$ fuel use test procedure.

A vehicle-level A/C fuel use test procedure is recommended that includes

- Soaking vehicle with solar lamps that meet SCO3 requirements or with an alternative heating method such as portable electric heaters. 
- Operating vehicle over repeated drive cycles or at a constant speed until steady-state cabin air temperature is attained.

- Running $\mathrm{A} / \mathrm{C}$ off and $\mathrm{A} / \mathrm{C}$ on tests to calculate a cooldown and steady-state $\mathrm{A} / \mathrm{C}$ fuel use.

The procedure measures the approximate real-world $\mathrm{A} / \mathrm{C}$ fuel use. Data are gathered for both cooldown and steady-state passenger compartment thermal conditions. The impact of thermal load reduction technologies can be measured using this procedure. This procedure can be used to characterize the impact of energy use for climate control on advanced vehicles as well as conventional vehicles.

While this paper focused on passenger compartment cooling, measuring the impact of passenger compartment heating on vehicles with electric powertrains is also critical. Thermal preheating of the passenger compartment using grid power can increase the electric range of PHEVs and EVs in the winter in addition to precooling in the summer.

\section{REFERENCES}

1. Rugh, J., Hovland, V., and Andersen, S., "Significant Fuel Savings and Emission Reductions by Improving Vehicle Air Conditioning," presented at Mobile Air Conditioning Summit, Washington, D.C., April 14-15, 2004.

2. Gonder, J., Markel, T., Thornton, M., and Simpson, A., "Using Global Positioning System Travel Data to Assess Real-World Energy Use of Plug-In Hybrid Electric Vehicles," Transportation Research Record:

Journal of the Transportation Research Board 2017:26-32, 2007, doi:10.3141/2017-04.

3. Official Journal of the European Union, Regulation (EC) No 443/2009, "Setting emission performance standards for new passenger cars as part of the Community's integrated approach to reduce CO2 emissions from light-duty vehicles," http://eur-

lex.europa.eu/LexUriServ/LexUriServ.do?uri=OJ:L:2009:140:0001:0015:EN:PDF, April 23, 2009.

4. State of California Assembly Bill No. 1493, http://www.arb.ca.gov/cc/ccms/documents/ab1493.pdf.

5. Final Regulation Order, Amendments to Sections 1900 and 1961, and Adoption of new Section 1961.1, Title 13, California Code of Regulations, http://www.arb.ca.gov/regact/grnhsgas/revfro.pdf.

6. Manufacturers Advisory Correspondence 2009-01, "Implementation of the New Environmental Performance Label," Mary D. Nichols, Chairman, http://www.arb.ca.gov/msprog/macs/mac0901/mac0901.pdf, February 24, 2009.

7. Meeting Minutes, State of California, Air Resources Board, Pages 118-273, http://www.arb.ca.gov/board/mt/2009/mt062509.pdf, June 25, 2009.

8. Environmental Protection Agency, 40 CFR Parts 86 and 600, "Fuel Economy Labeling of Motor Vehicles: Revisions To Improve Calculation of Fuel Economy Estimates; Final Rule," http://www.epa.gov/fedrgstr/EPA-AIR/2006/December/Day-27/a9749.pdf.

9. Proposed Rulemaking to Establish Light-Duty Vehicle Greenhouse Gas Emission Standards and Corporate Average Fuel Economy Standards, Environmental Protection Agency, 40 CFR Parts 86 and 600, Department of Transportation, National Highway Traffic Safety Administration, 49 CFR Parts 531, 533, and 537, Pages 257-275, http://www.nhtsa.dot.gov/portal/nhtsa static file_downloader.jsp?file=/staticfiles/DOT/NHTSA/Rulemakin g/Rules/Associated Files/MY2012-2016 CAFE_GHGN_PRM.pdf.

10. Papasavva, S., Hill, W., and Brown, R., "GREEN-MAC-LCCP®: A Tool for Assessing Life Cycle Greenhouse Emissions of Alternative Refrigerants," Proceedings of 2008 SAE Congress, Paper \# 2008-010829, Society of Automotive Engineers, Detroit, MI, 2008. 
11. Environmental Protection Agency, "Comparing the Climate Impacts of Mobile Air Conditioners: Global Refrigerants Energy \& Environmental Mobile Air Conditioning Lifecycle Climate Change Performance (GREEN-MAC-LCCP)C Model," http://epa.gov/cppd/mac/compare.htm.

12. SAE Technical Standards, "Life Cycle Analysis to Estimate the CO2-Equivalent Emissions from MAC Operation," J2766, February 2009, http://www.sae.org/technical/standards/J2766 200902.

\section{CONTACT INFORMATION}

John P. Rugh

National Renewable Energy Laboratory

1617 Cole Blvd.

Golden, CO 80401

john.rugh@nrel.gov

\section{ACKNOWLEDGMENTS}

The author gratefully acknowledges the support for this work provided by Lee Slezak and Patrick Davis in the Vehicle Technologies Program of the U.S. Department of Energy's (DOE) Office of Energy Efficiency and Renewable Energy. 


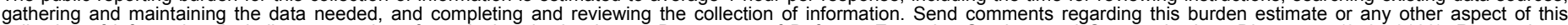

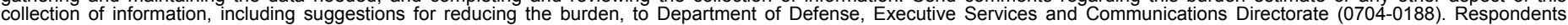

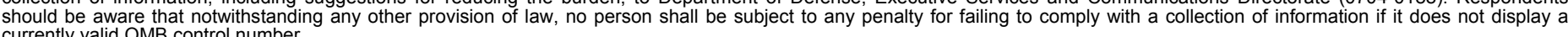

PLEASE DO NOT RETURN YOUR FORM TO THE ABOVE ORGANIZATION.

4. TITLE AND SUBTITLE

Proposal for a Vehicle Level Test Procedure to Measure Air

Conditioning Fuel Use: Preprint 5a. CONTRACT NUMBER

DE-AC36-08-GO28308

5b. GRANT NUMBER

5c. PROGRAM ELEMENT NUMBER

5d. PROJECT NUMBER

NREL/CP-540-47273

5e. TASK NUMBER

FC102300

5f. WORK UNIT NUMBER
7. PERFORMING ORGANIZATION NAME(S) AND ADDRESS(ES)

National Renewable Energy Laboratory

1617 Cole Blvd.

Golden, CO 80401-3393

9. SPONSORING/MONITORING AGENCY NAME(S) AND ADDRESS(ES)
8. PERFORMING ORGANIZATION REPORT NUMBER

NREL/CP-540-47273

10. SPONSOR/MONITOR'S ACRONYM(S) NREL

11. SPONSORING/MONITORING AGENCY REPORT NUMBER

\section{DISTRIBUTION AVAILABILITY STATEMENT}

National Technical Information Service

U.S. Department of Commerce

5285 Port Royal Road

Springfield, VA 22161

\section{SUPPLEMENTARY NOTES}

14. ABSTRACT (Maximum 200 Words)

The air-conditioning $(\mathrm{A} / \mathrm{C})$ compressor load significantly impacts the fuel economy of conventional vehicles and the fuel use/range of plug-in hybrid electric vehicles (PHEV). A National Renewable Energy Laboratory vehicle performance analysis shows the operation of the air conditioner reduces the charge depletion range of a 40-mile range PHEV from $18 \%$ to $30 \%$ in a worst case hot environment. Designing for air conditioning electrical loads impacts PHEV and electric vehicle (EV) energy storage system size and cost. While automobile manufacturers have climate control procedures to assess A/C performance, and the U.S. EPA has the SCO3 drive cycle to measure indirect $A / C$ emissions, there is no automotive industry consensus on a vehicle level $A / C$ fuel use test procedure. With increasing attention on $\mathrm{A} / \mathrm{C}$ fuel use due to increased regulatory activities and the development of PHEVs and EVs, a test procedure is needed to accurately assess the impact of climate control loads. This paper describes a procedure to measure approximate real-world $\mathrm{A} / \mathrm{C}$ fuel use and assess the impact of thermal load reduction strategies.

15. SUBJECT TERMS

plug-in hybrid electric vehicles; PHEV; electric vehicles; EV; thermal loads; air conditioning

\begin{tabular}{|c|c|c|c|c|}
\hline \multicolumn{3}{|c|}{ 16. SECURITY CLASSIFICATION OF: } & \multirow{2}{*}{$\begin{array}{l}\text { 17. LIMITATION } \\
\text { OF ABSTRACT } \\
\text { UL }\end{array}$} & \multirow{2}{*}{$\begin{array}{ll}\text { 18. } & \text { NUMBER } \\
\text { OF PAGES }\end{array}$} \\
\hline $\begin{array}{l}\text { a. REPORT } \\
\text { Unclassified }\end{array}$ & $\begin{array}{l}\text { b. ABSTRACT } \\
\text { Unclassified }\end{array}$ & $\begin{array}{l}\text { c. THIS PAGE } \\
\text { Unclassified }\end{array}$ & & \\
\hline
\end{tabular}

\begin{tabular}{l} 
19a. NAME OF RESPONSIBLE PERSON \\
19b. TELEPHONE NUMBER (Include area code) \\
\hline
\end{tabular}

